\title{
The Effects Of Teaching Techniques And Language Attitude Towards Student's Speaking Skill (Experiment At Private University In East Jakarta)
}

\author{
Suwantica Kusumandari \\ Faculty of Communication and Language \\ University of Bina Sarana Informatika \\ suwantica.ski@bsi.ac.id
}

\author{
Cara Sitasi: \\ Kusumandari, S. (2019). The Effects Of Teaching Techniques And Language Attitude Towards Student's \\ Speaking Skill (Experiment At Private University In East Jakarta). Wanastra, 11(1), 61-70.
}

\begin{abstract}
The purpose of this study was to: determine the interactional effects of teaching technique and language attitude towards student's speaking skill; determine the effect of teaching technique towards student's speaking skill; determine the effect of language attitude towards student's speaking skill; that were taught by role plays and filling information gap to the students. The research method used was experimental one. Sample size of 60 students consisting of 30 for experimental class and 30 for control class taken from Private University in East Jakarta, and the sampling technique used is cluster sampling. Research instruments used were the test to distinguish student's language attitude in the form of preferential test (20 items) and speaking skill in the form of oral test (5 items for scoring), that have been tested valid and reliable with coefficient of reliability at 0.839 and 0.705. The research uses two-ways ANOVA test. The results showed: 1) There is a significant effect of teaching technique towards student's speaking skill, as $F_{\text {observed }}=95.553>F_{\text {table }}=2.77$ and Sig $=0.000<0.05$. 2) There is a significant effect of language attitude towards student's speaking skill as $F_{\text {observed }}=10.617>F_{\text {table }}$ $=2.77$ and Sig $=0.002<0.05$. 3) There are significant interactional effects of teaching technique and language attitude towards student's speaking skill as $F_{\text {observed }}=8.199>F_{\text {table }}=2.77$ and Sig $=0.006<0.05$. 4) The group of students with positive language attitude would achieve more in speaking skill compared to another groups of language attitude if taught by using role plays technique. The results contribute most to the increasing of student's speaking skill.
\end{abstract}

Keywords: Teaching Technique, Language Attitude, Speaking Skill

\section{INTRODUCTION}

Since English as international language has already become one of the compulsory subjects of both senior and junior high school and beside for elementary school. In many countries including in Indonesia, it cannot be denied again, that the importance of English has gained a lot of attention from many people all over the world.

One of the language skills that have to be mastered by students in learning a foreign language is speaking.

Florez in Bailey (2006:2) stated that speaking is an interactive process of constructing meaning that involves producing and receiving and processing information. According to Bailey, speaking is the productive aural/oral skill which consists of producing systematic verbal utterances to convey meaning.
Achievement in mastering speaking skill to the students is also supported by students' language attitude. How hard the teacher teaches and how good the technique is are that the teacher use, is useless without students' language attitude.

\section{THEORETICAL REVIEW}

According to Anthony (1963:66) a technique is defined as a particular trick, stratagem, or contrivance used to accomplish an immediate objective. It is the part of tripartite framework proposed by Anthony.

Teaching technique is nowadays used into several forms of activities in the classroom. One of which is communicative language teaching (CLT). Hence we need to know about the CLT according to depiction below: 


\section{a. Communicative Language Teaching}

There are many ways to teach a language. One is called Communicative Language Teaching (CLT). Richards (2001:172) stated that Communicative Language Teaching is an approach which refers to a diverse set of principles that reflect a communicative view of language learning and that can be used to support a wide variety of classroom procedures. According to Brown (2000:266-267) CLT is best understood as an approach, not a method.

There are some learning and teaching techniques that can be used in Communicative Language Teaching class, for example, Role Play, Information Gap, language exchanges, simulation, discussion, game, pair work and group work. All these techniques can engage the learners in communication process.

\section{1) Role Play Technique}

One way of getting students to speak is to use Role Play activities in the classroom.

There are a lot of advantages both teacher and student can get from Role Play techniques which develops fluency in language students which promote interaction in the classroom, and which increases motivation. Further, Maley (1997:45-48) tells some reasons to use Role Play in language class. Here is a list of the main reasons: (a) Through Role Play activities, a very wide variety of experience can be brought into the classroom. (b) By using Role Play, the teacher can train the students in speaking skills in any situation. (c) Role Play puts students in the situation in which they are required to use and develop the language. (d) Students can try out and experiment with the language in a friendly and safe environment of a classroom. (e) Role Play can help many shy students by providing them with a mask. The students are deliberated by Role Play as they no longer feel that their own personality is implicated.

\section{2) Information Gap Technique}

Bailey (2005:191) stated that Information Gap technique refers to the activity in which learners must use the target language to convey information known to them but not to their speaking partners.

It can be concluded that Information Gap technique is a communicative language teaching technique which bring the language to life for students and usually involves pair work activities.

\section{3) The Distinction between Role Play and Information Gap}

Role Play and Information Gap are two among other techniques that can be used in communicative language classroom. Information Gap activity, on the other hand, is mostly about asking and answering questions in order to complete the information. One student has to listen to another student and then decide on how to respond in her own words according to the given situations. The following are the distinction between Role Play and Information Gap.

Table 1. The Distinction between Role Play and Information Gap

\begin{tabular}{|c|c|}
\hline Role Play & Information Gap \\
\hline It requires active participation of the learners. & $\begin{array}{l}\text { It requires extensive practice in asking and answering } \\
\text { questions. }\end{array}$ \\
\hline $\begin{array}{l}\text { Students usually consider this type of learning } \\
\text { fun. }\end{array}$ & $\begin{array}{l}\text { Students sometimes consider this activity is not so } \\
\text { interesting. }\end{array}$ \\
\hline $\begin{array}{l}\text { The activity can be applied in multiple } \\
\text { settings. }\end{array}$ & The activity is applied in limited setting. \\
\hline $\begin{array}{l}\text { It allows students to gain insight, or } \\
\text { understand the perspective of others. }\end{array}$ & $\begin{array}{l}\text { Students are suited to pair and usually rely upon pre- } \\
\text { prepared information cards. }\end{array}$ \\
\hline $\begin{array}{l}\text { Students can experience the target language in } \\
\text { context to learn how to interpret and } \\
\text { exchange meanings for real } \\
\text { communication. }\end{array}$ & $\begin{array}{l}\text { One student has to listen to her partner and then decide on } \\
\text { how to respond in her own words in the given situations. }\end{array}$ \\
\hline $\begin{array}{l}\text { Students use language freely only the setting } \\
\text { and the students' roles are determined by } \\
\text { the teacher, and students create } \\
\text { interaction. }\end{array}$ & $\begin{array}{l}\text { Teacher provides students with appropriate forms to be used } \\
\text { and meanings in dialogues. }\end{array}$ \\
\hline $\begin{array}{l}\text { Teacher can provide students with a variety of } \\
\text { learning experiences. }\end{array}$ & $\begin{array}{l}\text { Teacher can only provide students with limited learning } \\
\text { experience. }\end{array}$ \\
\hline
\end{tabular}




\section{Language Attitude}

According to Fasold (1984:148), the term language attitudes can also mean attitudes towards "all sorts of behaviour concerning language..., including attitudes toward language maintenance and planning effort".

\section{Mentalist View of Attitudes}

Many researchers think that attitudes are mentalist constructions. A famous definition is that of Allport in 1935, which states that an attitude is "a mental or neural state of readiness, organized through experience, exerting a directive or dynamic influence upon the individual's response to all objects and situations with which it is related" (Allport 1935 as quoted by Baker 1992:11). According to this view, attitudes are hypothetical constructs.

In the mentalist tradition, attitudes are often represented as forming a three-component model (Oskamp, 1991:8-9) This tradition stems as far back as Plato (Baker 1992: 12). A three-component model of attitudes is demonstrated in Figure 2.1 below.

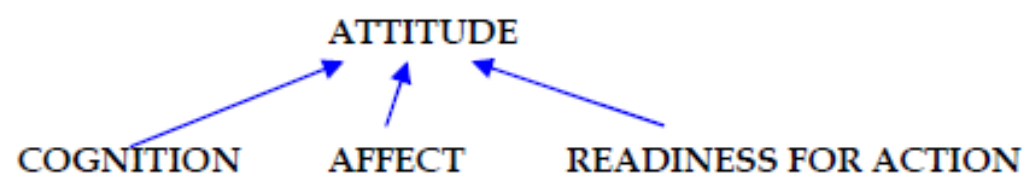

Figure 1. A Three-Component Model of Attitude (Baker, 1992:13)

The three-component model of attitudes can be explained by the definition of Rosenberg and Hovland (1960:3, as quoted by Eiser 1986:53), according to which: "attitudes are predispositions to respond to some class of stimuli with certain classes of response", those classes of response being affective, cognitive and behavioural (or conative).

\section{a. Behaviourist and Discursive View of Attitudes}

A second view of attitudes is the behaviourist view. This differs from the mentalist view in that in the behaviourist view, attitudes are viewed as single units, which are found simply in the responses people make to social situations, i.e. as response to stimulus (Fasold, 1984:147-148).

\section{Speaking Skill}

As a matter of fact, speaking is one of communication skills in which the speaker shares information while at the same he/she also gets information from the listener.

Caney (1998:13) as quoted by Kayi stated that "speaking is the process of building and sharing meaning through the use of verbal and non-verbal symbols, in a variety of context." By speaking someone can communicate his ideas or information, and share them to others at any situations and in a various contexts.

In assessing the speaking skill, Underhill (2004:96) stated that there are five aspects should be measured; fluency, grammar, pronunciation, vocabulary, and comprehension. Brown (2004: 57) stated that there are six cases to be evaluated in accordance with the speaking assessment; (1) grammar, (2) vocabulary, (3) comprehension, (4) fluency, (5) pronunciation, and (6) task (accomplishing the objective of elicit task)

\section{The Effect of Teaching Techniques towards Student' Speaking Skill.}

.By using the communicative language teaching technique, the teacher can facilitate the communicative activities so that the students will be encouraged to get involved in the communication process which can possibly improve their speaking skill.

There are some techniques related to communicative language teaching, and two of them are Role Play and Information Gap. It could be assumed that the students who were taught the Role Play techniques will get better speaking skill than using the Information Gap technique.

\section{The Effect of Language Attitude towards Students' Speaking Skill.}

Language attitude is an expression of favor or disfavor towards all sorts of behaviour concerning language, including attitudes toward language maintenance and planning effort.

It means the success in achieving the student's speaking skill, is mostly determined by how good is the teachers motivate the student's attitude towards English lesson. 


\section{The Interactional Effects of Teaching Technique and Language Attitude towards Students' Speaking Skill.}

Using the most effective technique in teaching speaking is not an easy task for the teacher, due to the fact that there are other factors that can affect the success of learning and teaching process. One of them is student's language attitude.

CLT techniques require the students to be actively involved in the language learning process.

\section{RESEARCH METHOD}

This research used experiment method, which means to give the different treatments upon two students' learning groups. One group is treated as experiment group, which is given treatment of teaching method by using role plays, while another group is given treatment of teaching approach by using filling gap information.

This research has 2 kinds of validity. They are internal validity and external validity. Internal validity is related to the effect of treatment towards student's speaking skill, which based on the accuracy of the procedure, collected data and summing up the conclusion. While external validity is related to whether the result of the research could be generalized to another subjects which do not have the similarity in condition and characteristic as well. In order to achieve the goal, hence through this research, there are some controls on the extra variables as follows:

1. The effect of history variable, which means during this research, the sample will be given the same subject, the same period, and the same teacher.

2. The effect of readiness variable, which means during this research, the sample will be given the treatment in a short period of time.

3. The effect of pre-testing variable, which means two-group of students, will not be given the pre-test.

4. The effect of instrument variable, which means both group of students (experiment and conventional) are controlled by giving them the same kind of test.

5. The effect of mortality variable, which means other students who are not the sample, will be given the same treatment during the research so that if the mortality happens

6. The effect of interaction among the subjects, which means the sample will not know anything during the research whether the process or the learning activity.

Meanwhile, the efforts to control the external validity of this research are taken as follows:

1. The learning interaction by using role play technique, filling information gap and also language attitude is taken on equal-two-groups (experiment class and control class

2. The control of reactive research

This research used experimental method with $2 \times 2$ factorial designs, which stated as follow:

Table 2. Research Design

\begin{tabular}{|c|c|c|c|}
\hline \multirow{2}{*}{$\begin{array}{c}\text { Language } \\
\text { Attitude }\end{array}$} & $\begin{array}{c}\text { Role Plays } \\
\left(\mathrm{A}_{1}\right)\end{array}$ & $\begin{array}{c}\text { Filling Gap } \\
\left(\mathrm{A}_{2}\right)\end{array}$ & \multirow{2}{*}{ TOTAL } \\
\cline { 2 - 3 } & $\mathrm{A}_{1} \mathrm{~B}_{1}$ & $\mathrm{~A}_{2} \mathrm{~B}_{1}$ & $\sum \mathrm{B}_{1}$ \\
\hline $\begin{array}{c}\text { Positive } \\
\left(\mathrm{B}_{1}\right)\end{array}$ & $\mathrm{A}_{1} \mathrm{~B}_{2}$ & $\mathrm{~A}_{2} \mathrm{~B}_{2}$ & $\sum \mathrm{B}_{2}$ \\
\hline $\begin{array}{c}\text { Negative } \\
\left(\mathrm{B}_{2}\right)\end{array}$ & $\sum \mathrm{A}_{1}$ & $\sum \mathrm{A}_{2}$ & $\sum$ TOTAL \\
\hline TOTAL & & & \\
\hline
\end{tabular}

$\mathrm{A}_{1} \mathrm{~B}_{1}$ : Positive Language Attitude with Role Plays Technique.

$A_{1} B_{2}$ : Negative Language Attitude with Role Plays Technique.

$\mathrm{A}_{2} \mathrm{~B}_{1}$ : Positive Language Attitude with Filling Information Gap Technique.

$\mathrm{A}_{2} \mathrm{~B}_{2}$ : Negative Language Attitude with Filling Information Gap Technique. 


\section{POPULATION AND SAMPLE}

\section{Target Population}

The target population of this research is all varsity students of Private Islamic University in East Jakarta, possesses more than 2562 students which is divided into several parallel departments/classes, where each class consists of more or less 25 students.

\section{Scope Population}

Refer to the problem of this research; the scope population is varsity students (English Education Department) of Private Islamic University in East Jakarta, in even semester of academic year 20122013, total 115 students who are divided into 5 parallel classes where each class consists of approximately 20-25 students.

\section{Sample}

According to Sudjana (1992:6), sample is a part of population. In this research, total sample is 60 students, who are divided into 2 classes; one experiment class consists of 30 students, and one control class consists of 30 students as well. The experiment classes are class $\mathrm{A}$ and $\mathrm{B}$, while the control classes are class $\mathrm{C}$ and $\mathrm{D}$, which all classes are the students of English Education Department from the same university. In this research, there are 4 groups with different treatment and different ability. The clustering of the sample is stated in the following:

\section{Table 3. The Sample Cluster}

\begin{tabular}{|c|l|c|}
\hline Group & \multicolumn{1}{|c|}{ Character of the Subjects and Kind of Treatment } & Students \\
\hline I & $\begin{array}{l}\text { Group of students with positive language attitude with Role Plays } \\
\text { Technique. }\end{array}$ & 15 \\
\hline II & $\begin{array}{l}\text { Group of students with negative language attitude with Role Plays } \\
\text { Technique. }\end{array}$ & 15 \\
\hline III & $\begin{array}{l}\text { Group of students with positive language attitude with Filling } \\
\text { Information Gap Technique. }\end{array}$ & 15 \\
\hline IV & $\begin{array}{l}\text { Group of students with negative language attitude with Filling } \\
\text { Information Gap Technique. }\end{array}$ & 15 \\
\hline \multicolumn{1}{|c}{ TOTAL } & $\mathbf{6 0}$ \\
\hline
\end{tabular}

\section{Sampling Technique}

The sampling technique of this research is intact class based on factorial group design, with the following steps: (a) choose the location for this research; (b) choose the classes for this research; (c) choose the sample for this research by making random sampling, which means every student's name is dropped into a closed-cup of glass, and then one by one is chosen after shaking it first. Those are chosen, will be automatically the sample of this research; (d) collect all the students' name before giving them the instrument of the research. The sample-choosing of this research is taken into 2 phases:

a. First phase, deciding the four classes for this research. Since there are only 4 classes taken, so two classes are set for experiment while another two classes are set for control class.

b. Second phase, taking the sample according to the students' numbering. In this research, the subjects taken are based on his/her attitude

\section{TECHNIQUE AND COLLECTING DATA}

\section{Variable of Research}

Variables of this research are:

a. Independent variable 1 or treatment variable (A) which is teaching technique with role plays and filling information gap.

b. Independent variable 2 or attributive variable (B) which is language attitude with positive and negative manner.

c. Dependent variable or criterion variable (Y) which is student's English speaking skill for the purposely designed refers to the standardized one.

\section{Source of Data}

In this research, all data is gained from students. For further information, we can see the table below: 
The Effect Of Teaching Techniques And Language Attitude Towards Student's Speaking Skill (Experiment At Private University In East Jakarta)

Table 4. Source of Data

\begin{tabular}{|l|c|}
\hline \multicolumn{1}{|c|}{ Variables of Research } & Source of Data \\
\hline Teaching technique (role plays and filling information gap) & Students \\
\hline Language attitude & Students \\
\hline Speaking skill & Students \\
\hline
\end{tabular}

\section{Method of Collecting Data}

The data for this research is collected through

Table. 5 Method of Collecting Data

\begin{tabular}{|l|c|}
\hline \multicolumn{1}{|c|}{ Variable of Research } & Technique of Collecting Data \\
\hline Teaching technique & Treatment on the field \\
\hline Language attitude & Preferential Test \\
\hline Speaking Skill & Oral Test \\
\hline
\end{tabular}

\section{DISCUSSION}

\section{Data Description}

According to the result of data analysis which has been done, the resume of data gained through the research is presented as follows:

Table 6. Description of Research Data

\begin{tabular}{|c|c|c|c|}
\hline \multirow[b]{2}{*}{ Language Attitude (B) } & \multicolumn{2}{|c|}{ Teaching Technique (A) } & \multirow{2}{*}{ TOTAL } \\
\hline & $\begin{array}{l}\text { Role Plays } \\
\qquad\left(\mathbf{A}_{1}\right)\end{array}$ & $\begin{array}{l}\text { Filling Gap } \\
\qquad\left(\mathbf{A}_{2}\right)\end{array}$ & \\
\hline \multirow{3}{*}{$\begin{array}{c}\text { Positive Language } \\
\text { Attitude } \\
\left(\mathbf{B}_{1}\right)\end{array}$} & $\mathrm{n}=15$ & $\mathrm{n}=15$ & $\mathrm{n}=30$ \\
\hline & $\bar{Y}=20.47$ & $\bar{Y}=18.13$ & $\bar{Y}=19.3$ \\
\hline & $\mathrm{s}=1.73$ & $\mathrm{~s}=1.19$ & $\mathrm{~s}=1.46$ \\
\hline \multirow{3}{*}{$\begin{array}{c}\text { Negative Language } \\
\text { Attitude } \\
\left(\mathrm{B}_{2}\right)\end{array}$} & $\mathrm{n}=15$ & $\mathrm{n}=15$ & $\mathrm{n}=30$ \\
\hline & $\bar{Y}=20.33$ & $\bar{Y}=16.07$ & $\bar{Y}=18.2$ \\
\hline & $\mathrm{s}=0.9$ & $\mathrm{~s}=1.28$ & $\mathrm{~s}=1.09$ \\
\hline \multirow{3}{*}{ TOTAL } & $\mathrm{n}=30$ & $\mathrm{n}=30$ & $\mathrm{n}=60$ \\
\hline & $\bar{Y}=20.4$ & $\bar{Y}=17.1$ & $\bar{Y}=18.75$ \\
\hline & $\mathrm{s}=1.31$ & $\mathrm{~s}=1.23$ & $\mathrm{~s}=1.27$ \\
\hline
\end{tabular}

Explanation:

$\mathrm{A}_{1} \mathrm{~B}_{1} \quad$ : Positive Language Attitude treated with Role Plays.

$\mathrm{A}_{1} \mathrm{~B}_{2} \quad$ : Negative Language Attitudes treated with Role Plays.

$\mathrm{A}_{2} \mathrm{~B}_{1} \quad$ : Positive Language Attitude treated with Filling Information Gap.

$\mathrm{A}_{2} \mathrm{~B}_{2} \quad$ : Negative Language Attitude treated with Filling Information Gap.

\section{Score of Student's Speaking Skill}

Scoring the data for speaking skill is done by using instrument with oral test (speaking skill test) and the total items to be assessed are 5. For each item will be graded according to the student's skill from 1 to 5 . Hence the maximum score will be 25 , while minimum score will be 5 . Respondents for experimental group are 30 students, taught by using role plays approach with different preference of language attitudes. While another 30 students (control group) are taught by using filling information gap with different preference of language attitudes. The empiric score stated that the highest score is 23 , the lowest score is 13 . Furthermore, mean is 18.75 , median is 19 , mode is 19, standard of deviation is 2.22 and variance is 4.936. The complete result gained from calculation can be seen on Table 7 below: 


\section{Table 7. Research Data}

Statistics

\begin{tabular}{|l|r|}
\begin{tabular}{|l|r|} 
Sneaking_Skill \\
N Valid \\
Mean & 60 \\
Missing & 0 \\
Median & 18.75 \\
Mode & 19.00 \\
Std. Deviation & 19 \\
Variance & 2.222 \\
Minimum & 4.936 \\
Maximum & 14 \\
\hline
\end{tabular}
\end{tabular}

The mean 18.75 indicates that the average score for the students is relatively good. The standard of deviation 2.22 indicates that the speaking skill given by students whether using role plays or filling information gap are relatively the same. To make it clear, we can see the display of histogram and polygon presented below:

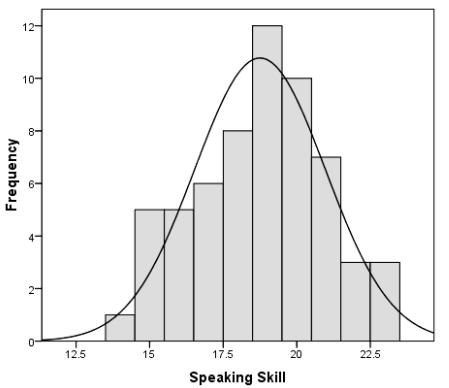

Figure 2. Histogram and Polygon of Student's Speaking Skill

\section{The Prerequisite Test for Data Analysis}

Variable data of the research which will be processed by using inferential technique though ANOVA test must be fulfilled several prerequisites.

Thus, the normality test and the homogeneity test must be done first before the ANOVA test conducted. The result of the test is presented in the following:

\section{Normality Test}

Normality test is used to find out whether the spreading data is distributed normally or not. To test the normality, the Lilliefors test is used. If the result of $\mathrm{L}_{\text {observed }}>\mathrm{L}_{\text {table }}$, it means that $\mathrm{H}_{0}$ stated that the spreading data distributed normally is rejected, and on the contrary $\mathrm{H}_{1}$ is accepted.
The normality test is done to both groups by using statistical hypotheses formula stated as follows:

$$
\begin{aligned}
& \mathrm{H}_{0}=\text { sample data is distributed normally } \\
& \mathrm{H}_{1}=\text { sample data is not distributed normally }
\end{aligned}
$$

The computation is performed with the assistance of SPSS version 16.0 for Windows. According to the criteria of this program, the data is normal if $p$ value $(\mathrm{Sig})>0.05$ which means $\mathrm{H}_{0}$ is accepted and on the contrary $\mathrm{H}_{1}$ is rejected (data is distributed normally). The score of $p$ value (Sig) is the number on the column of Sig from the table of normality test outcome by using SPSS program. In this case, the method used is Kolmogorov-Smirnov. The computation of normality test can be seen on the table below:

Table 8. Recapitulation of Normality Test

\begin{tabular}{|ll|r|}
\multicolumn{2}{|c|}{ One-Sample Kolmogorow-Smirnow Test } \\
\hline \multicolumn{2}{|c|}{} & Speaking Skill \\
\hline N & & 60 \\
Normal Parameters $^{2}$ & Mean & 18.75 \\
& Std. Deviation & 2.222 \\
Most Extreme Differences & Absolute & .128 \\
& Positive & .075 \\
& Negative & -128 \\
Kolmogorow-Smirnov $Z$ & & .992 \\
Asymp. Sig. (2-tailed) & .278 \\
\hline
\end{tabular}


According to Table 4.3 above, it can be seen that the scores on Sig column by using KolmogorovSmirnov method for student's speaking skill is mentioned: 0.278 which means the $p$ value score for student's speaking skill is bigger than 0.05 hence, $\mathrm{H}_{0}$ is accepted and $\mathrm{H}_{1}$ is automatically rejected. In other words, it may be concluded that all data from the sample of this research have been distributed normally.

\section{Homogeneity Test}

Besides normality test, one prerequisite test mostly needed to analyze the data using ANOVA is homogeneity test. The homogeneity test for the data of student's speaking skill is performed by using Levene's test in the significant level of $5 \%$. The result of homogeneity computation can be seen on the Table 4.4 below:

Table 9. The Computation of Homogeneity Test for Student's Speaking Skill

Levene's Test of Equality of Error Variances ${ }^{*}$

\begin{tabular}{|c|c|c|c|}
\hline$F$ & df1 & $\mathrm{df} 2$ & Siq. \\
\hline 3.374 & 3 & 56 & .065 \\
\hline
\end{tabular}

The hypotheses for homogeneity test are set as follows:

$\mathrm{H}_{0} \quad$ : Data comes from homogenous population

$\mathrm{H}_{1} \quad$ : Data comes from non-homogenous population

The criteria are set as follows:

If the Sig value (Levene's test) > 0.05; means that $\mathrm{H}_{0}$ is accepted and $\mathrm{H}_{1}$ is automatically rejected. On the contrary, the Sig value (Levene's test) $<0.05$; means that $\mathrm{H}_{1}$ is accepted and $\mathrm{H}_{0}$ is automatically rejected.

Refer to Table 4.4 above; we can see that the Sig ( $p$ value) for speaking skill is 0.065 . It means that $p$ value is bigger than 0.05 . It brings consequence that $\mathrm{H}_{0}$ is accepted and $\mathrm{H}_{1}$ is automatically rejected, which implies that data comes from homogenous population.

According to both normality test and homogeneity test revealed above, it can be concluded that the prerequisite tests which are needed before processing the data by using ANOVA test are already fulfilled.

\section{Testing the Hypothesis}

Having had the normality test and also homogeneity test, we can see that the data is distributed normally and the data also comes from homogenous population. Hence, in order to test the hypothesis by using ANOVA can be done directly.

The analysis of student's speaking skill variable is performed by using two ways ANOVA test, with the assistance of SPSS version 16.0 for Windows. The result of ANOVA test then continued to extended test to find out the level of significance among groups significantly (simple effect). In other words, the extended test is performed to find out which group contributes more to the student's speaking skill according to the teaching techniques and also the preference of language attitude.

The computation of data analysis by using ANOVA test can be seen on the Table 10 below

\section{Tabel 10. ANOVA Test}

\section{Tests of Between-Subjects Effects}

\begin{tabular}{|c|c|c|c|c|c|}
\hline Source & $\begin{array}{l}\text { Type III Sum } \\
\text { of Squares }\end{array}$ & $\mathrm{df}$ & Mean Square & $\mathrm{F}$ & Sig. \\
\hline Corrected Model & $195.517^{a}$ & 3 & 65.172 & 38.123 & .000 \\
\hline Intercept & 21093.750 & 1 & 21093.750 & $1.234 E 4$ & .000 \\
\hline Teaching_Technique & 163.350 & 1 & 163.350 & 95.553 & .000 \\
\hline Language_Attitude & 18.150 & 1 & 18.150 & 10.617 & .002 \\
\hline $\begin{array}{l}\text { Teaching_Technique * } \\
\text { Language_Attitude }\end{array}$ & 14.017 & 1 & 14.017 & 8.199 & .006 \\
\hline Error & 95.733 & 56 & 1.710 & & \\
\hline Total & 21385.000 & 60 & & & \\
\hline Corrected Total & 291.250 & 59 & & & \\
\hline
\end{tabular}

a. R Squared $=, 671$ (Adjusted R Squared $=, 654$ ) 


\section{Testing The Fisrt Hypothesis: There is Effect of Teaching Technique towards Student's Speaking Skill}

Testing this hypothesis is by seeing the coefficient of significance. If the value of $\mathrm{Sig}>0.05$, it means that $\mathrm{H}_{0}$ is accepted and $\mathrm{H}_{1}$ is automatically rejected. On the other hand, if the value of Sig $<0.05$ it means that $\mathrm{H}_{0}$ is rejected and $\mathrm{H}_{1}$ is automatically accepted.

The computation performed by using SPSS version 16.0 for Windows is found that the value of Sig for teaching approach is $0.000<0.05$ and $\mathrm{F}_{\text {obserrved }}$ (95.553) $>F_{\text {table }}$ (2.77). It can be concluded that there is a significant effect of teaching technique towards student's speaking skill.

Testing The Second Hypothesis: There is Effect of Language Attitudes towards Student's Speaking Skill

Testing this hypothesis is by seeing the coefficient of significance. If the value of $\mathrm{Sig}>0.05$, it means that $\mathrm{H}_{0}$ is accepted and $\mathrm{H}_{1}$ is automatically rejected. On the other hand, if the value of $\mathrm{Sig}<0.05$ it means that $\mathrm{H}_{0}$ is rejected and $\mathrm{H}_{1}$ is automatically accepted.

The computation performed by using SPSS version 16.0 for Windows is found that the value of Sig for language attitude is $0.002<0.05$ and $\mathrm{F}_{\text {obserrved }}$ (10.617) $>\mathrm{F}_{\text {table }}$ (2.77). It can be concluded that there is a significant effect of language attitude towards student's speaking skill

This research was designed to find the effects of teaching technique and language attitude towards student's speaking skill for the major of English at Private University in East Jakarta.

Based on the findings and supported by statistical analysis for the research about student's speaking skill, it is proved that data comes from population which is distributed normally and comes from homogenous variances.

It means that the data has fulfilled the prerequisite tests of data analysis. Then the data is processed to test about the hypothesis. From the testing of hypothesis, it is gained that:

1. There is an effect of teaching technique towards student's speaking skill. Based on the testing of hypotheses the score of significance $(\mathrm{Sig})$ is 0.000 and $\mathrm{F}_{\text {observed }}=95.553$ meanwhile $\mathrm{F}_{\text {table }}=2.77$. Since the score of $\mathrm{Sig}<0.05$ and $\mathrm{F}_{\text {observed }}>\mathrm{F}_{\text {table }}$ so $\mathrm{H}_{0}$ is rejected and $\mathrm{H}_{1}$ is accepted, which means there is a significant effect of independent variable (teaching technique) towards dependent variable (student's speaking skill).

2. There is an effect of language attitude towards student's speaking skill. Based on the testing of hypothesis the score of significance ( $\mathrm{Sig}$ ) is 0.002 and $\mathrm{F}_{\text {observed }}=10.617$ sedangkan $\mathrm{F}_{\text {table }}=$ 2.77. Since the score of Sig $<0.05$ and $F_{\text {observed }}$ $>\mathrm{F}_{\text {table }}$ so $\mathrm{H}_{0}$ is rejected and $\mathrm{H}_{1}$ is accepted, which means there is a significant effect of independent variable (language attitude) towards dependent variable (student's speaking skill).

V. There are interactional effects of teaching technique and language attitude towards student's speaking skill. Based on the testing of hypotheses the score of significance $(\mathrm{Sig})$ is 0.006 and $\mathrm{F}_{\text {observed }}=8.199$ meanwhile $\mathrm{F}_{\text {table }}=$ 2.77. Since the score of Sig $<0,05$ and $F_{\text {observed }}$ $>\mathrm{F}_{\text {table }}$ so $\mathrm{H}_{0}$ is rejected and $\mathrm{H}_{1}$ is accepted, which means there are interactional effects of independent variables (teaching technique and language attitude) towards dependent variable (student's speaking skill) and the interaction .

\section{CONCLUSION}

Refer to the results taken from the testing of research hypotheses and analysis of data processing, it can be concluded as follows:

1. There is a significant effect of teaching technique towards student's speaking skill at Private University in East Jakarta. This means that student's speaking skill is affected by teaching technique, which in this case role plays and filling information gap.

2. There is a significant effect of language attitude towards student's speaking skill at Private University in East Jakarta. This means that the more positive a student's preference in language attitude, the higher the student's speaking skill.

On the contrary, the more negative a student's preference in language attitude, the lower the student's speaking skill. Therefore, language attitude is an important variable to consider in predicting English speaking skill of the student. Based on the test results with the correlation coefficient using the formula obtained by ANOVA analysis, $F_{\text {observed is }}$ 10.617 while the score of $F_{\text {table }}$ is 2.77 . While the score of Sig $0.002<$ than 0.05 .

3.There are significant interactional effects of teaching technique and language attitude towards student's speaking skill at Private 
University in East Jakarta. It means that the student's speaking skill is largely determined by both teaching technique (role plays and filling information gap) and language attitude. This shows that the teaching technique (role plays and filling information gap) and language attitude are two importanat variables (essential factors) to be considered in explaining the increase of student's speaking skill. ANOVA analysis of the results, obtained $\mathrm{F}_{\text {observed }}$ is 8.199 .

\section{REFERENCES}

Ajzen, I. 1988. Attitudes, Personality and Behaviour. Milton Keynes: Open University Press.

Antony, E. M. 1963. Approach, Method, Technique. Seminal of English Language Teaching, 17, 63-67.

Bailey, Katleen M. 2005. Practical Language Teaching: Speaking. New York McGraw Hill.

Baker, C. 1992. Attitudes and Language. Clevedon: Multilingual Matters.

Caney, Hayriye. 1998. Teaching Speaking: Activiies to Promote Speaking in Second Language. Nevada: University of Nevada. (retrieved on 26 June 2013 at http://unr/edu/homepage/hayriye)

Eiser, R.J. 1986. Social Psychology: Attitudes, Cognition and Social Behaviour. Cambridge: Cambridge University Press.

Fasold, R. 1984. The Sociolinguistics of Society. Oxford: Basil Blackwell.

Gardner, R.C. 1985. Social Psychology and Second Language Learning: The Role of Attitudes and Motivation. London: Edward Arnold.
Gardner, R.C. and W.E. Lambert 1972. Attitudes and Motivation in Second Language Learning. Rowley, MA: Newbury House.

Hyperdictionary. 2007. Meaning of Skill. New York: Longman Pearson.

Kodotchigova, Maria. 2008. A, Role Play in Teachong Culture. Russia: Tomsk State University Russia (retrieved on 5 June 2013 at http://iteslj.org /Techniques/Kodotchigova RolePlay.html)

Maley, Alan. 2005. Drama Techniques: A Resource Book of Communication Activities for Language Teachers. Cambridge: Cambridge University Press.

Oskamp, S. 1991. Attitudes and Opinions. Englewoord Cliffs, NJ: Prentice Hall.

Potter, J. and M. Wetherell. 1987. Discourse and Social Psychology. London: Sage.

Richard, Jack C. and Theodore S. Rodger. 1982. Approaches and Methods in Language Teaching. UK: Cambridge University Press.

Rees, Gareth. 2008. Find the Gap-Increasing Speaking in Class. London: British Council. (retrieved on 20 May 2013 at htpp://www. teachingenglish.org.uk.think.speak.find.gap. shtml)

Savignon, Sandra J. in Marianne Celce \& Murcia (Ed). 2001. Communicative Language Teaching for the Twenty First Century. United States of America: Heinle\&Heinle Inc.,

Underhill, Nic. 2004. Testing Spoken Language: A Hand Book of Oral Testing Techniques. Cambridge: Cambride University Press.

Wood, Caroline. 2005. Teaching and Assessing Skills in Foreign Languages: Professional Development for Teachers. United Kingdom: Cambridge University Press.

\section{BIOGRAPHY}

Suwantica Kusumandari earned her Bachelor's degree from Department of English Languages, University of Indraprasta PGRI in 2007 and later her Master's Degree in English Education from University of Indraprasta PGRI in 2013. Currently she is a lecturer University of Bina Sarana Informatika and she can be reached through suwantica.ski@bsi.ac.id. 